Louisiana State University

LSU Digital Commons

Faculty Publications

Department of Oceanography \& Coastal

Sciences

$12-4-2017$

Dinoflagellate Cysts Track Eutrophication In The Northern Gulf Of Mexico

Andrea M. Price

Melissa M. Baustian

R. Eugene Turner

Nancy N. Rabalais

Gail L. Chmura

Follow this and additional works at: https://digitalcommons.Isu.edu/oceanography_coastal_pubs

Part of the Oceanography Commons 


\title{
Dinoflagellate Cysts Track Eutrophication in the Northern Gulf of Mexico
}

\author{
Andrea M. Price ${ }^{1,2} \cdot$ Melissa M. Baustian $^{3} \cdot$ R. Eugene Turner $^{2} \cdot$ Nancy N. Rabalais ${ }^{2,4} \cdot$ Gail L. Chmura $^{1}$ \\ Received: 27 October 2016 / Revised: 14 November 2017 / Accepted: 18 November 2017 / Published online: 4 December 2017 \\ (C) Coastal and Estuarine Research Federation 2017
}

\begin{abstract}
We examined organic-walled dinoflagellate cysts from one ${ }^{210} \mathrm{~Pb}$-dated sediment core and 39 surface sediment samples from the northern Gulf of Mexico to determine the relationship between nutrient enrichment and cyst assemblages in this region characterized by oxygen deficiency. The core spans from 1962 to 1997 and its sampling location is directly influenced by the Mississippi River plume. Surface sediments were collected in 2006, 2007, 2008, and 2014 and represent approximately 1 to 4 years of accumulation. A total of 57 cyst taxa were recorded, and four heterotrophic taxa in particular were found to increase in the top section (1986-1997) of the core-Brigantedinium spp., cysts of Archaeperidinium minutum, cysts of Polykrikos kofoidii, and Quinquecuspis concreta. These taxa show a similar increasing trend with variations in US fertilizer consumption and Mississippi River nitrate concentrations, both of which increased substantially in the 1970s and 1980s. The same four heterotrophic taxa dominated dinoflagellate cyst assemblages collected near the Mississippi River Bird's Foot Delta where nutrient concentrations were higher, especially in 2014 . We propose that these cyst taxa can be used as indicators of eutrophication in the Gulf of Mexico. A canonical correspondence analysis (CCA) supports this proposition. The CCA identified sea-surface nutrient concentrations, sea-surface temperature, and sea-surface salinity as the most important factors influencing the cyst assemblages. In addition, cysts produced by the potentially toxic dinoflagellates Pyrodinium bahamense and Lingulodinium polyedrum were documented, but did not appear to have increased over the past 50 years.
\end{abstract}

Keywords Sediments $\cdot$ Nutrients $\cdot$ Mississippi River $\cdot$ Atchafalaya River $\cdot$ Plankton $\cdot$ Hypoxia $\cdot$ Dead zone

\section{Introduction}

The northern Gulf of Mexico (NGOM) is well known for its nutrient enrichment and seasonal hypoxic zone. Both are due to

Communicated by Hans W. Paerl

Electronic supplementary material The online version of this article (https://doi.org/10.1007/s12237-017-0351-x) contains supplementary material, which is available to authorized users.

Andrea M. Price

andrea.price@mail.mcgill.ca

1 Department of Geography, McGill University, Burnside Hall Building, 805 Sherbrooke Street West, Montreal, QC H3A 0B9, Canada

2 Department of Oceanography and Coastal Sciences, Louisiana State University, 1002-Q Energy, Coast and Environment Building, Baton Rouge, LA 70803, USA

3 The Water Institute of the Gulf, One American Place, 301 N. Main Street, Suite 2000, Baton Rouge, LA 70825, USA

4 Louisiana Universities Marine Consortium, 8124 Highway 56, Chauvin, LA 70344, USA the influence of the Mississippi River, which drains over $41 \%$ of the conterminous US and delivers an average of $1.6 \times 10^{6}$ metric tons of nitrogen to the Gulf each year (Goolsby et al. 1999). This large supply of nutrients fuels phytoplankton blooms, and once the organic matter is respired, the bottom waters and sediments may become depleted of oxygen. Stratification of the water column limits replenishment of oxygen, resulting in dissolved oxygen (DO) levels of $\leq 2 \mathrm{mg} \mathrm{L}^{-1}$ starting in spring and developed by summer (hypoxic zones; e.g., Rabalais et al. 2007a).

The Mississippi and Atchafalaya rivers account for approximately $98 \%$ of the nitrogen and phosphorus loads in the region where hypoxia occurs (Trinity River through to the Mississippi Delta) (Rabalais et al. 2007a). The Louisiana Coastal Current flows from east to west during non-summer months transporting Mississippi plume waters primarily west of the Mississippi Bird's Foot Delta and weakens in summer (Nowlin et al. 2005). Currently, $80 \%$ of nitrogen and $60 \%$ of phosphorus from the Mississippi River Basin is derived from agricultural sources, mainly fertilizer (White et al. 2014). Fertilizer use in the USA began to rise in the early 1950s and increased substantially in the late 1960s and throughout the 1970s (Rabalais et al. 1999; USDA 2016). Nutrient 
concentrations (nitrogen and phosphorus) in the Mississippi River rose concurrently. While the use of phosphorus fertilizers plateaued in the 1980s, the use of nitrogen fertilizers continued to rise, albeit at a much slower pace (USDA 2016). Nitrate concentrations in the Mississippi River are more than double what they were pre-1950 (e.g., Rabalais and Turner 2001). The discharge of the Atchafalaya River includes the Red River and 30\% of the Mississippi River flow. The Atchafalaya River enters the northern Gulf of Mexico about $400 \mathrm{~km}$ to the west of the Mississippi River Delta. These anthropogenic sources of nutrient enrichment are responsible for the eutrophication of the NGOM.

Biological indicators have been used to study eutrophication and hypoxia in the NGOM and include microfossil diatoms (e.g., Parsons and Dortch 2002) and foraminifera (e.g., Sen Gupta et al. 1996; Osterman 2003; Platon et al. 2005; Osterman et al. 2005, 2008, 2009). Parsons and Dortch (2002) examined Pseudo-nitzschia from five sediment cores and found that it increased in all cores in response to coastal eutrophication. Two foraminifera indices have been identified as proxies for hypoxia in the NGOM: (1) the AmmoniaElphidium (A-E) index (Sen Gupta et al. 1996) and (2) the Pseudononion atlanticum, Epistominella vitrea, and Buliminella morgani or PEB index (Osterman 2003; Osterman et al. 2005, 2008, 2009). Changes in both indices suggest increasing oxygen stress during the twentieth century (Sen Gupta et al. 1996; Osterman 2003; Osterman et al. 2005, 2008, 2009).

Organic-walled dinoflagellate cysts are another microfossil group known to reflect eutrophication (e.g., Dale and Fjellså 1994; Matsuoka 1999; Pospelova et al. 2002; Dale 2009; Price et al. 2017b). Dinoflagellate cysts are advantageous diagnostic (paleo)environmental indicators because they are well preserved in the sedimentary record and are not subject to dissolution. Dinoflagellates are protists that comprise a significant portion of planktonic communities. Approximately half of dinoflagellate species are heterotrophic, while the other half are autotrophic or mixotrophic (Dale 2009), providing an ideal opportunity to study both primary producers and microzooplankton. Many dinoflagellates produce meiotic resting cysts in the upper water column that sink to the seafloor as part of its life cycle (e.g., Dale 1996). Cysts can remain dormant in the sediment from weeks to over a century (Lundholm et al. 2011) before they excyst, and the motile stage then re-enters the water column. Cyst assemblages are known to reflect changes in sea-surface parameters including sea-surface temperature (SST), sea-surface salinity (SSS), nutrient availability, productivity, and ice-cover (e.g., Dale 1996; Matsuoka 1999; de Vernal et al. 2001; Radi et al. 2007; Price et al. 2013; Zonneveld et al. 2013). Potentially toxic dinoflagellates, such as Pyrodinium bahamense and Lingulodinium polyedrum, are among the species that produce a significant number of recognizable cysts.
Two main dinoflagellate cyst indices that indicate eutrophic conditions have been described. The first, commonly referred to as the "Oslofjord signal," is characterized by an increase in total cyst concentrations and an increase in the abundance of the autotrophic species Lingulodinium machaerophorum (Dale and Fjellså 1994; Dale et al. 1999; Dale 2009). The second one is characterized by an increase in cysts produced by heterotrophic taxa. In many regions, cysts produced by heterotrophic dinoflagellates become more abundant in response to increased nutrients from natural sources such as upwelling (e.g., Wall et al. 1977; Powell et al. 1992; Marret et al. 2013; Bringué et al. 2014) or from anthropogenic sources (e.g., Pospelova et al. 2002; Matsuoka et al. 2003; Kim et al. 2009; Price et al. 2017b). Heterotrophic dinoflagellates graze on other microplankton such as diatoms that also respond to nutrient sources. The most commonly reported cysts of heterotrophic taxa that increase in abundance because of eutrophication are Selenopemphix quanta, cysts of Polykrikos kofoidii/schwartzi, cysts of Protoperidinium americanum, Dubridinium spp., and Brigantedinium spp. (e.g., Pospelova et al. 2002; Matsuoka et al. 2003; Krepakevich and Pospelova 2010; Pospelova and Kim 2010; Shin et al. 2010). Which heterotrophic species or combination of species increase in response to eutrophication is related to differences in prey composition, availability, and variable feeding mechanisms (Jacobson and Anderson 1986; Hansen 1991; Hansen and Calado 1999; Naustvoll 2000). For example, the Diplopsalis group are generalists in their feeding behavior (Naustvoll 2000), while many Protoperidinium species graze exclusively on diatoms (Jeong 1999). Different feeding mechanisms such as pallium (feeding veil), peduncle (feeding tube), and engulfment methods can regulate the size of prey that is able to be consumed (Jeong et al. 2010). In addition to $L$. machaerophorum, other cyst species of autotrophic dinoflagellates can become more abundant in response to increased nutrient availability (e.g., in the Po River discharge plume, Zonneveld et al. 2012; Boston Harbor, Delaware Bay, Prince Edward Island, Price et al. 2017b), but this signal is not geographically widespread. Autotrophic taxa may be at a disadvantage in nutrient-rich systems due to competition with other more rapidly reproducing phytoplankton groups such as diatoms, light limitation (Dale 2009), and top-down control by grazers.

Few studies have examined dinoflagellate cyst assemblages from Gulf of Mexico surface sediments (Limoges et al. 2013; Edwards and Willard 2001) or late Quaternary sediment cores (e.g., Wrenn 1988; van Soelen et al. 2010; Limoges et al. 2014, 2015), and none that we know of have analyzed NGOM shelf sediments that are directly impacted by the Mississippi River Basin discharge. Limoges et al. (2013) recently provided valuable information on dinoflagellate cysts 
from surface sediment samples in the southern GOM, near the Florida coast, and offshore (>500 m water depth) in the NGOM. They examined the influence of SST, SSS, productivity, water depth, and distance to coast on cyst assemblages and identified distance to coast/water depth and SST as being the most important factors influencing dinoflagellate cyst distributions in that region. Other GOM cyst studies have not directly considered nutrients as influential factors on cyst accumulation. Information is, therefore, lacking about the effect of nutrients on dinoflagellates and their cyst assemblages in the GOM.

Our study examined the temporal and spatial records of dinoflagellate cyst assemblages from one 20 -cm-long sediment core at station F35 (Fig. 1) and from 39 surface sediments collected from 26 stations across the central NGOM. Station F35 is located in the modern hypoxic zone and is influenced by the Mississippi River plume. Sediment samples from core F35 are therefore able to capture changes in eutrophication over time. Our aim was to document how dinoflagellate cysts reflect nutrient enrichment in the NGOM by examining the temporal and spatial variations in cyst assemblages and comparing them to complementary nutrient measurements. We hypothesized that (1) the eutrophication signal recorded by dinoflagellate cysts would manifest itself as an increase in cysts produced by heterotrophic taxa and (2) the concentrations of heterotrophic taxa would be greatest near the major distributaries because of the proximity to nutrientrich Mississippi and Atchafalaya river waters. We tested these two hypotheses by conducting a canonical correspondence analysis (CCA) on cyst assemblages from surface sediments along with environmental parameters (inorganic sea-surface nutrient concentrations, temperature, salinity, and distance to nearest river mouth) to determine which factors had a significant impact on cyst distributions.

\section{Materials and Methods}

\section{Study Area}

The northern Gulf of Mexico is mostly a shallow $(<50 \mathrm{~m}$ deep) continental shelf. The Mississippi and Atchafalaya rivers discharge onto the shelf and significantly influence the abiotic (e.g., temperature, salinity, stratification), biotic (e.g., plankton dynamics), and ecological conditions. These rivers are the main source of fresh water to the NGOM, accounting for $96 \%$ of the annual riverine discharge (Rabalais et al. 2007a). Stratification increases with increasing discharge and surface water temperatures and thus is greatest during spring and summer. A stratified water column supports the seasonal development of hypoxic bottom-water.

The in situ primary productivity is seasonally and annually variable and is heavily influenced by river discharge and the nutrients it contains. The highest levels of primary production and chlorophyll $a$ typically occur at salinities of 20-30 psu and on the inner shelf (Lohrenz et al. 1999; Rabalais and Turner 2001). This can be attributed to the nutrient loading from the Mississippi and Atchafalaya rivers that stay in the photic zone and because of stratification. While diatoms are one of the dominant phytoplankton groups in the NGOM, changes in nutrients ratios, in particular a decrease in the Si:N ratio, may alter the phytoplankton community and promote flagellates (Rabalais and Turner 2001).

The size and distribution of nutrient-rich plume waters, in part, controls the extent of the hypoxic zone area, which in mid-summer spans from the western side of the Mississippi River Delta, across the Louisiana shelf to the upper Texas coast (e.g., Rabalais and Turner 2001; Rabalais et al. 2007a). It can extend to $125 \mathrm{~km}$ offshore and in water depths of $\sim 4$ $60 \mathrm{~m}$ (Rabalais et al. 2007a).

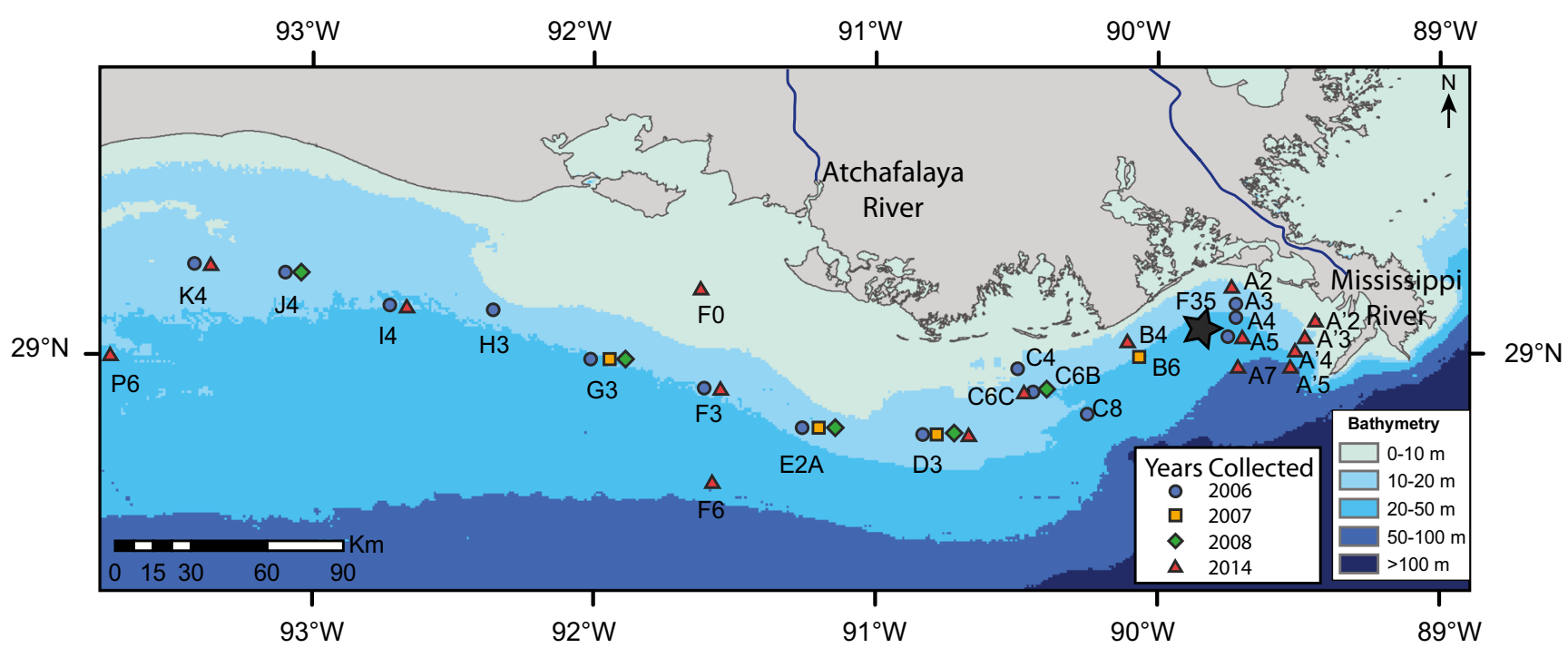

Fig. 1 Locations of surface sediments collected in 2006, 2007, 2008, and 2014 (colored symbols) and core F35 collected in 1997 (star). The exact sampling locations are in ESM 1 


\section{Sediment Collection and Sample Preparation}

One sediment core was analyzed that was collected in 1997 from station F35 in a water depth of approximately $35 \mathrm{~m}$ (Fig. 1). The core was stored in a cold room at $4{ }^{\circ} \mathrm{C}$ before sectioning in 2012. The upper $4 \mathrm{~cm}$ was sectioned into $1 \mathrm{~cm}$ intervals and into $2 \mathrm{~cm}$ intervals below $4 \mathrm{~cm}$. The core was composed primarily of silt and clay-sized particles (Rabalais et al. 2004) and showed no visual evidence of sediment disturbance. The core was dated using ${ }^{210} \mathrm{~Pb}$ analyses described by Turner et al. (2004). Sedimentation rates were calculated based upon the ${ }^{210} \mathrm{~Pb}$ decay constant and the decay and excess activity of ${ }^{210} \mathrm{~Pb}$ with depth (Nittrouer et al. 1979), providing an average sedimentation rate of $0.57 \mathrm{~cm}_{\text {year }}^{-1}$ (Price et al. 2017a). Price et al. (2017a) estimated that the core sedimentation was from 1962 to 1997 based on the average sedimentation rate and the core length.

A total of 39 surface sediment samples were collected from 4 years: 14 from 2006, four from 2007, five from 2008, and 16 from 2014 (Electronic Supplementary Material (ESM) 1, Fig. 1). Sediments from 2006 to 2008 were subsamples from those analyzed by Baustian et al. (2011, 2013) and were composed of $>75 \%$ mud, except those from stations D3 and E2A which were 25-75\% mud (Baustian et al. 2013). Sediment was collected in all years using a GOMEX box corer $(50 \times 30 \times 30 \mathrm{~cm})$. The surface-water interface was maintained as $7.6-\mathrm{cm}$ diameter acrylic core tubes were used to take subsamples from the box corer. The top $0.5 \mathrm{~cm}$ was removed from each core using a precision core extruder in 2006-2008. The top $2 \mathrm{~cm}$ was removed in 2014. Surface samples were stored in a freezer until analysis. Sedimentation rates in the NGOM range from approximately 0.41 to $1.24 \mathrm{~cm} \mathrm{year}^{-1}$, and the greatest rates are found near the Mississippi River Bird's Foot Delta (Rabalais et al. 2007b). Sediments from 2006 to 2008 and 2014 were collected for different projects and therefore encompass different sampling depths. Sediments collected in 20062008 represent the top $0.5 \mathrm{~cm}$ and, based on the sedimentation rates reported by Rabalais et al. (2007b), corresponds to approximately 1 year of sedimentation. Sediment samples in 2014 represent the top $2 \mathrm{~cm}$, equivalent to approximately 4 years of sedimentation. Due to differences in the amount of time the surface samples represent ( $\sim 1$ vs. $\sim 4$ years), the complementary environmental data to which the assemblages were compared also represent 1 or 4 years.

Sediments were processed using a palynological treatment method (e.g., Pospelova et al. 2010) and described by Price et al. (2017a). Sediments were first oven-dried and weighed. One Lycopodium clavatum tablet containing 13,911 spores was added to calculate absolute cyst abundances. Room temperature $10 \%$ hydrochloric acid $(\mathrm{HCl})$ and $48 \%$ hydrofluoric acid (HF) were used to dissolve carbonates and silicates. The sediments were washed through a $120-\mu \mathrm{m}$ sieve and retained on a $15-\mu \mathrm{m}$ sieve. They were sonicated for less than $1 \mathrm{~min}$. Organic walled dinoflagellate cysts were identified and counted at $\times 400$ to $\times 600$ magnifications. From 112 to 513 cysts were counted in each sample, with an average of 363 . Cyst concentrations were calculated using the equation of Benninghoff (1962):

$c=\frac{d_{\mathrm{c}} \times L_{\mathrm{t}} \times t}{L_{\mathrm{c}} \times w}$

where

$c$ concentration number of dinoflagellate cysts/gram dried sediment

$d_{\mathrm{c}} \quad$ number of dinoflagellate cysts counted

$L_{\mathrm{t}} \quad 13,911$ Lycopodium spores/tablet

$t \quad$ number of tablets added to the sample

$L_{\mathrm{c}} \quad$ number of Lycopodium spores counted

w weight of dried sample (g)

Cyst concentrations can vary with grain size. Increasing grain size often reflects higher energy environments and a reduced potential for cyst deposition (Dale 1983). Thus, their concentrations are lower in samples dominated by sand compared to silt. The relative abundances are not affected in this way, but suffer from the closed sum effect, whereby an increase (or decrease) in the relative abundance of one species results in the relative decrease (or increase) in the others.

Cysts were given species names by biostratigraphers until the $\sim 1960$ s when it was established that they were produced by dinoflagellates (e.g., Dale 1983); thus, many have paleontological names. The taxonomic affinity between the motile stage and cyst stage has yet to be determined for many dinoflagellates; therefore, the paleontological nomenclature is used in this study. However, some cysts are named after the motile stage if the cyst-motile stage relationship is known (e.g., cyst of Polykrikos kofoidii). For sake of brevity, the term "cyst of" will not be used, except the first time they are mentioned. Dinoflagellate cysts were identified following Zonneveld and Pospelova (2015) and Mertens et al. (2017). Round brown cysts have a thin brown wall that is often folded or collapsed in appearance and where the shape of the diagnostic archeopyle is partially obscured or not visible because of the cyst orientation. These cysts likely belong to the Protoperidinaceae or Diplopsalid groups. Cysts produced from heterotrophic and autotrophic dinoflagellates will henceforth be referred to as heterotrophic and autotrophic taxa, respectively. A list of all cyst taxa and their motile stage equivalents is given in ESM 2 and photo plates are in ESM 3. Cyst concentrations are provided in the ESM 4-5 and relative abundances in ESM 6-7. 


\section{Environmental Data}

The corresponding environmental data were averaged from the year prior (summer months only-June to August) for sediment collected in 2006-2008 and averaged over 4 years for sediment collected in 2014 (2011-2014 summer months only). Summer sea-surface temperature data were obtained from bi-monthly MODerate resolution Imaging Spectroradiometer (MODIS) imagery, the World Ocean Database (WOD) (http://www.nodc.noaa.gov/OC5/ SELECT/dbsearch/dbsearch.html), and from conductivitytemperature-depth (CTD) measurements made on yearly mid-summer cruises. Summer bottom dissolved oxygen (BDO) levels, sea-surface salinity (SSS), and surface inorganic nutrient (nitrate and nitrite, ammonium, phosphate) concentrations were obtained from the WOD and mid-summer cruises. The environmental data are in ESM 1.

\section{Statistical Analyses}

A canonical correspondence analysis (CCA) was used to assess the relationship between the percentage of dinoflagellate cyst taxa in the surface sediments and environmental parameters. Rare taxa with abundances $<1 \%$ were excluded from the analysis. Sediment collection occurred between 2006 and 2014 encompassing a range of environmental conditions (Fig. 2), but due to the sparse spatial coverage in 2007 and 2008 ( $\leq 5$ samples/year), only samples collected in 2006 and 2014 ( $\geq 14$ samples/year) were included in the CCA. The length of the first gradient in detrended correspondence analysis (DCA) was 2.4 indicating unimodal variation and justified using a CCA. The variables that were statistically significant $(p<0.05)$ in explaining variations in the cyst assemblage were determined using a step-constrained analysis and a Monte Carlo permutation test, with 499 unrestricted permutations. A principal component analysis (PCA) was used on the dinoflagellate cyst relative abundances in core F35. Due to a lack of historical environmental data from station F35, a CCA or other constrained analysis could not be performed on the core data. Multivariate statistical techniques were performed using CANOCO 4 and 5.0 for Windows (ter Braak and Šmilauer 2002, 2012). Pearson correlations were calculated using IBM SPSS to determine the degree of correlation between environmental parameters.

\section{Results}

\section{Trends in Cyst Taxa—Core F35 (1962-1997)}

Heterotrophic taxa comprised $65-85 \%$ of the assemblages throughout the core and increased towards the top, with the exception of the surface sample. The concentrations of the heterotrophic taxa Brigantedinium spp., A. minutum, P. kofoidii, and $Q$. concreta increased noticeably during the late 1980 s and remained high throughout the rest of the core (Fig. 5). Consequently, the ratio of heterotrophic to autotrophic taxa was higher in sediments from the 1980s-1990s $(\sim 5)$ compared to that from the 1960s-1970s ( 3) (Fig. 5).

The PCA ordinated samples from 1986 to 1997 on the right side, while those from 1962 to 1985 were ordinated on the left side (Fig. 6). Many of the taxa that correlated with higher nutrients and lower SSSs in the surface samples (e.g., A. minutum, P. kofoidii, and Brigantedinium spp.) were located on the far right (Fig. 6), suggesting that the first axis represents a gradient in nutrient availability. Axis 1 explained $60.2 \%$ of the variation in the cyst assemblage, and axis 2 explained $16.7 \%$. All autotrophic taxa were located on the left hand side of the diagram, with the exception of M. choanophorum (Fig. 6).

\section{Trends in Hydrography_Surface Samples}

The average SSTs varied from $\sim 29.5-31.0{ }^{\circ} \mathrm{C}$ across the study area, and the inter-annual variation in summer SSTs at a single station was $\sim 1{ }^{\circ} \mathrm{C}$ or less (Fig. 2). The largest range in salinities occurred in transects $\mathrm{A}$ and $\mathrm{A}^{\prime}$ which were located near the mouth of the Mississippi River Delta. This was particularly evident in the summers of 2011-2014 when the SSSs were as low as $\sim 13$ psu (Fig. 2). Many of these low-salinity stations also had high concentrations of nitrate + nitrite $(>$ 5 umol L ${ }^{-1}$ ). The average phosphate concentrations were highest across all sites in summers of 2011-2014 compared to those of 2006-2008. The ammonium concentrations in 2007 at the four stations were high (Fig. 2).

The sea-surface salinities negatively correlated with nitrate $(r=-0.766, p<0.0001)$ and phosphate concentrations $(r=$ $-0.719, p<0.0001)$, and the nitrate and phosphate concentrations positively correlated with each other $(r=0.798$, $p<0.0001$ ) (Table 1). The highest average annual discharge rates as well the greatest nitrogen and phosphorus loads occurred in 2008, while they were lowest in 2006 (Price et al. 2017a, their Table 2; USGS 2016).

\section{Trends in Cyst Taxa-Surface Samples}

The number of dinoflagellate cyst taxa per sample ranged from 15 to 37 and was lowest in 2006 and highest in 2014.

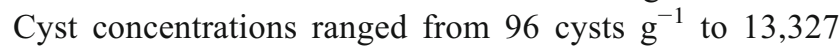
cysts $\mathrm{g}^{-1}$. The average proportion of heterotrophic taxa ranged from 13 to $82 \%$, and average heterotrophic concentrations varied from 128 to 3365 cysts g $^{-1}$ (2006 and 2014). The average concentrations of autotrophic taxa varied from 334 to 1081 cysts $^{-1}$ (2008 and 2006) (Figs. 2 and 3). The ratio of heterotrophic taxa to autotrophic taxa (H/A) was lowest is 

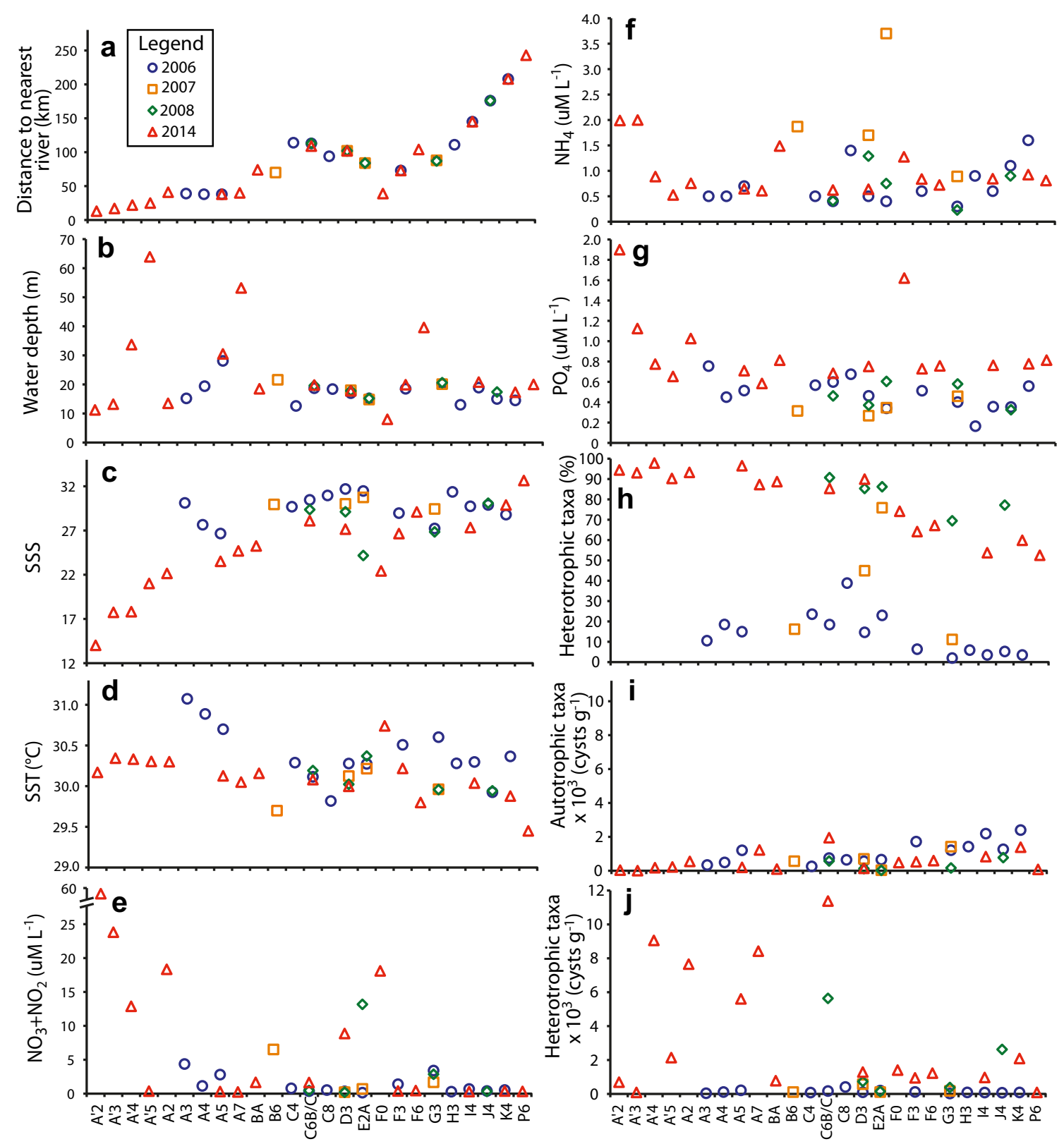

Fig. 2 Environmental and physical data for each station displayed by station, where different years are represented by symbols. a Distance to the nearest river. b Water depth. c Average sea-surface salinity. d Average summer sea-surface temperature. e Average summer surface water nitrate + nitrite concentrations. f Average summer surface water ammonium

2006 (average 0.1) and highest in 2014 (average 10.9), and in 2014, samples from transects $\mathrm{A}^{\prime}, \mathrm{A}$, and B near the delta had an average $\mathrm{H} / \mathrm{A}$ ratio of 19 compared to the rest of the study area which had a lower average ratio of 3.2 (ESM 4).

The heterotrophic taxa that were more abundant in 2014, especially near the Mississippi River Bird's Foot Delta, are Brigantedinium spp., Archaeperidinium minutum, P. kofoidii, and $Q$. concreta (Fig. 3a-d) and to a lesser extent $S$. quanta and cysts of Peridinium minutum sensu Wall and Dale 1968. In contrast, with the exception of L. machaerophorum, the concentrations. g Average summer surface water phosphate concentrations. $\mathbf{h}$ Relative abundance of cysts produced by heterotrophic taxa. $\mathbf{i}$ autotrophic and $\mathbf{j}$ heterotrophic cyst concentrations (cysts $\mathrm{g}^{-1}$ ). Figure legend in a

dominant autotrophic taxa (Polysphaeridium zoharyi, Spiniferites spp., Nematosphaeropsis labyrinthus, and Spiniferites ramosus) showed no clear spatial or temporal trend (Fig. 3e-h). The cyst concentrations were lower at stations E2A and D3, near the Atchafalaya River, compared to those at the other stations (Fig. 3). Samples from E2A and D3 collected from 2006 to 2008 contained a higher proportion of sand compared to those from the other stations in the study area (Baustian et al. 2013) ( $55 \%$ vs. $8 \%$, respectively), likely causing, at least in part, the lower cyst concentrations. 
Table 1 Pearson correlation coefficients between summer averaged sea-surface temperature (SST); sea-surface salinity (SSS); sea surface ammonium, nitrate + nitrite, and phosphate concentrations; bottom water dissolved oxygen (BDO)

concentrations; and water depth

\begin{tabular}{lrllllll}
\hline & SST & SSS & Ammonium & Nitrate + nitrite & Phosphate & BDO & Depth \\
\hline SST & & & & & & \\
SSS & -.291 & & & & & \\
Ammonium & -.105 & -.138 & & & & \\
Nitrate + nitrite & .151 & $-.766^{* *}$ & .306 & & & \\
Phosphate & .238 & $-.719^{* *}$ & .158 &. $\mathbf{7 9 8}$ & & \\
BDO & .050 & -.073 & -.004 & -.120 & & \\
Depth & -.015 & -.220 & -.254 & -.242 & -.114 & .259 \\
\hline
\end{tabular}

** Correlation is significant at the 0.01 level (two-tailed)

\section{Relationships Between Cysts and Environmental Parameters}

The CCA results are displayed in ordination diagrams of species scores (Fig. 4a) and sample scores (Fig. 4b). The SSS,
SST, nitrate + nitrite, phosphate concentrations, and distance to the nearest river were statistically significant $(p<0.05)$ environmental parameters. The ammonium concentration was not significant. The first CCA axis had an eigenvalue of 0.491 and axis two had a value of 0.057 . Together, the two
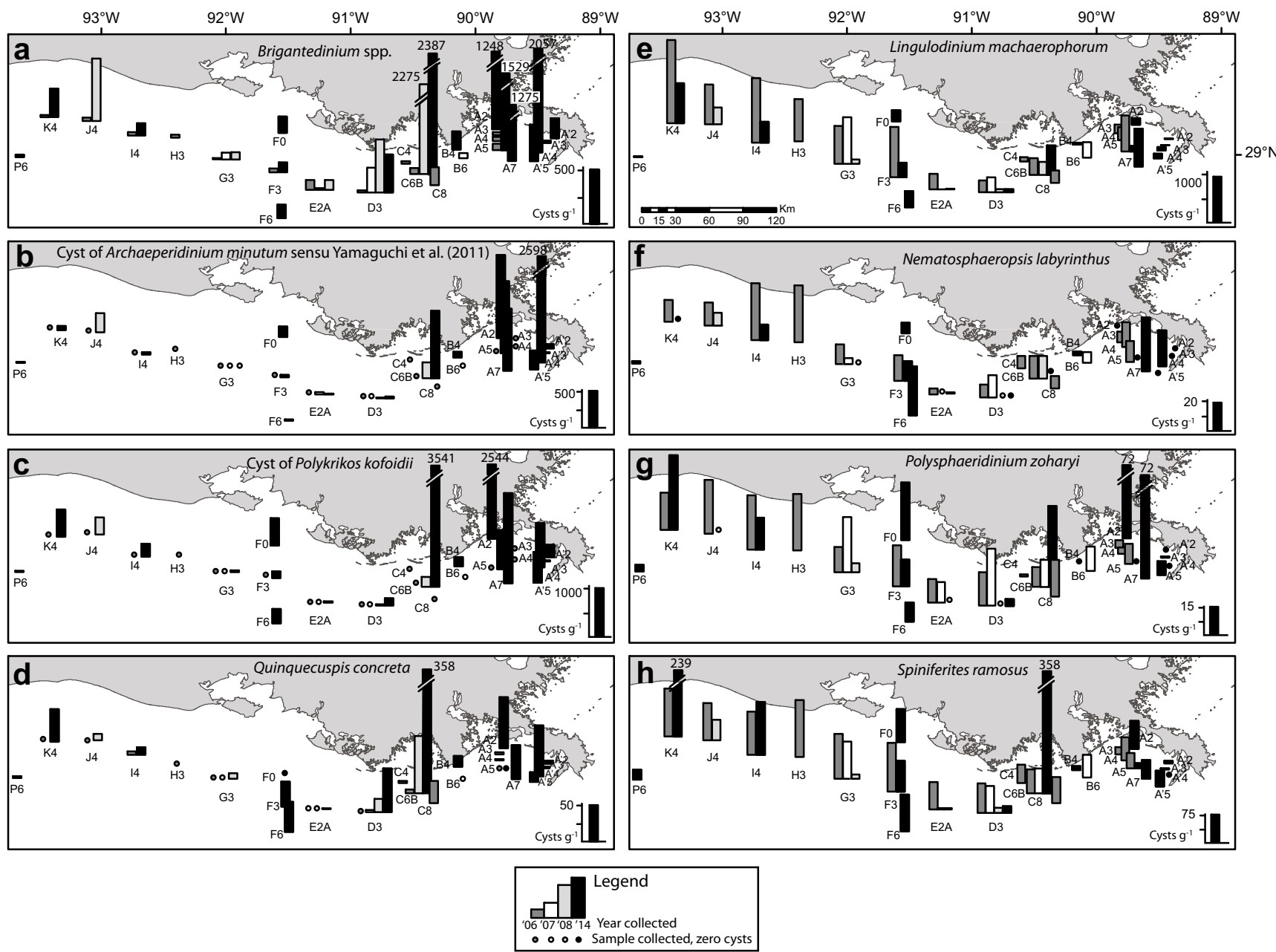

Fig. 3 Concentrations (cysts $\mathrm{g}^{-1}$ ) of four cysts produced by heterotrophic taxa that are proposed eutrophication indicators $(\mathbf{a}-\mathbf{d})$ and four common cysts produced by autotrophic taxa (e-h). a Brigantedinium spp. b Cysts of Archaeperidinium minutum. c Cysts of Polykrikos kofoidii. d Quinquecuspis concreta. e Lingulodinium machaerophorum. f Nematosphaeropis labyrinthus. g Polysphaeridinium zoharyi. $\mathbf{h}$
Spiniferites ramosus. Samples were collected in 2006, 2007, 2008, and 2014 and are differentiated by shading. Circles indicate if a sample was collected, but if no cysts of that particular species were found. Bar heights are proportional to cyst concentrations. The scale is different for each species. For precise sample locations see ESM 1 
axes explained over $50 \%$ of the variation in the cyst assemblages.

Heterotrophic and autotrophic taxa formed two distinct clusters and were ordinated on opposite sides of the diagram (Fig. 4a). Heterotrophic taxa correlated to higher nutrient concentrations as well as to lower summer SSSs and SSTs. Autotrophic taxa displayed the opposite relationship, positively correlating with higher SSSs and negatively with nutrient concentrations (Fig. 4b).

Samples collected from 2014 correlated with higher nutrients, lower SSSs and SSTs, and all but one had a positive CCA1 score. In contrast, samples from 2006 were generally ordinated on the left side of the diagram and correlated with higher SSSs, higher SSTs, and lower nutrients (Fig. 4b).

\section{Discussion}

Cysts produced by heterotrophic taxa increased in abundance throughout the core and rose more rapidly in the 1980s and 1990s following trends in US fertilizer consumption and Mississippi River nitrate concentrations. Heterotrophic taxa were also more abundant near the mouth of the Mississippi Delta, especially in 2014 when surface water nutrient concentrations were higher and Mississippi River discharge was greater than in 2006. In contrast, samples collected in 2006, when nutrient concentrations were lower than in 2014, were dominated by autotrophic taxa. Our discussion focuses on the eutrophication signal, both temporally and spatially in the
NGOM. First, we consider possible taphonomic processes that may have affected the cyst assemblages.

\section{Dinoflagellate Cyst Preservation and Potential Resuspension}

Dinoflagellate cysts from aerobic sediments can be affected by selective degradation (e.g., Zonneveld et al. 2010), particularly in areas with low sedimentation rates. The seasonally hypoxic bottom waters and high sedimentation rates $\left(\mathrm{mm}\right.$ year $^{-1}$ ) of the NGOM may promote the preservation of organic-walled dinoflagellate cysts. All the dinoflagellate cysts we found appeared to be well preserved and the walls of sensitive cysts, notably heterotrophic taxa, showed no signs of degradation, suggesting that the taxonomic record was complete.

Resuspension and reworking of sediments along the Louisiana continental shelf are possible due to hurricanes which frequent the Gulf of Mexico. Resuspension of sediment not only causes mixing, but may also cause cyst concentrations to increase (Kamiyama et al. 2014). For example, in Sendai Bay (Japan), cyst densities of Alexandrium were found to be up to ten times greater after the 2011 tsunami than before (Kamiyama et al. 2014). The distribution of ${ }^{210} \mathrm{~Pb}$ in core $\mathrm{F} 35$ was linear with depth and had no outliers (Price et al. 2017a) which suggests mixing via resuspension or bioturbation was low.

Maps of hurricane tracks from 2006 to 2014 (https:// www.tropical weather.net/hurricane-tracks.html) were analyzed to evaluate conditions affecting the distribution of cysts in the surface sediment samples during strong storms. Hurricanes occurred in the study region in 2008 and 2012.

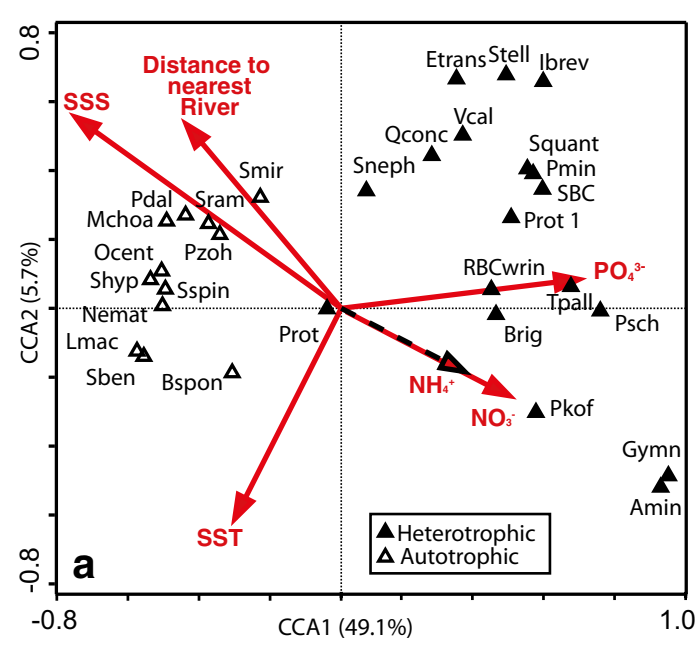

Fig. 4 Canonical correspondence analysis (CCA) ordination diagrams of the relative abundance of dinoflagellate cysts in surface sediments (2006 and 2014) and environmental parameters. Environmental parameters that are statistically significant $(p<0.05)$ are shown by solid arrows, and those

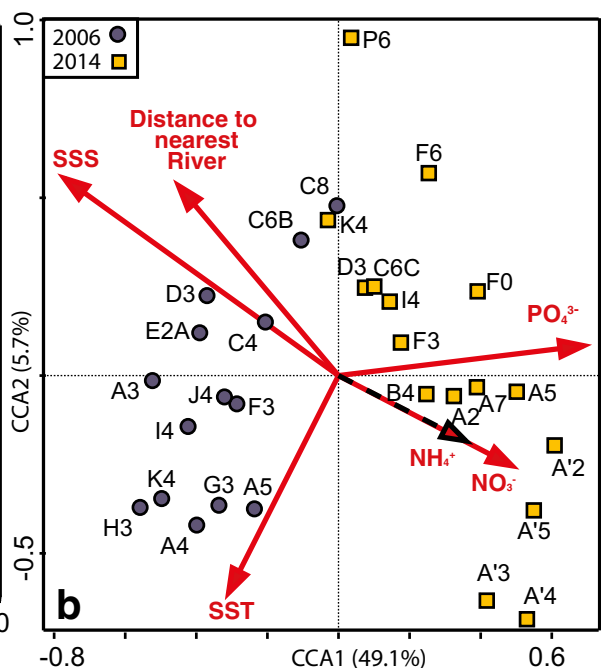

which were not are shown by black dashed arrows. a Species scores. Full cyst names are listed in Electronic Supplementary Material 2. b Sample scores. SSS, sea surface salinities; SST, sea surface temperatures 
Hurricane Dolly crossed over the western GOM in 2008, but it did not affect the bottom dissolved oxygen (BDO) concentrations at station C6B (Baustian et al. 2013), suggesting that the sea bottom was not disturbed. Hurricane Isaac passed over the Mississippi River Delta in 2012 and likely caused resuspension in part of the study area because the $\mathrm{BDO}$ increased rapidly during the hurricane at station $\mathrm{C} 6 \mathrm{C}$ (Rabalais, unpublished data). While cyst concentrations of some heterotrophic taxa were higher in samples collected in 2014 compared to those in the 2006-2008 samples, if resuspension was the cause then we would expect concentrations of all taxa to be higher than those in previous years-but this is not observed (Figs. 2i, j and 3). Thus, the increase in heterotrophic taxa is not likely due to resuspension.

\section{Temporal Changes in Eutrophication from the 1960s to 1990s}

Heterotrophic taxa and four species in particularBrigantedinium spp., P. kofoidii, A. minutum, and $Q$. concreta - had increased concentrations from 1986 to 1997 compared to those from 1962-1985 (Figs. 5 and 6). The 1980s and 1990s were characterized by high nutrients loads and peak nitrate concentrations in the Mississippi River (e.g., Scavia et al. 2003), due to increasing fertilizer usage in the US. The clustering of samples from 1986 to 1997 and the location of these four taxa on the right side of the PCA ordination diagram (Fig. 6) suggest that the first PCA axis reflects a gradient in nutrients, with greater nutrient availability on the right side of the diagram. The PCA axis 1 scores correlate to nutrient loading $(r=0.689, p=0.028)$ further supporting this claim.

Fertilizer use in the USA increased substantially in the 1970s and 1980s (e.g., Rabalais et al. 2007a) and resulted in an increase in nutrient concentrations in the Mississippi River. The abundance of autotrophic dinoflagellate cysts (phytoplankton) in core F35 showed little variation, but there was a noticeable increase in cysts of heterotrophic dinoflagellates. The abundance of heterotrophic taxa likely reflects an increase in prey availability, such as diatoms, and indirectly the increase in nutrients. This interpretation is supported by the changing concentration of chlorophyll $a$ and phytoplankton pigments (e.g., zeaxanthin, alloxanthin, fucoxanthin) from a F35 replicate core, which increased, especially in the mid-1980s (Rabalais et al. 2004), as well as the relative abundance of both biogenic silica (Parsons and

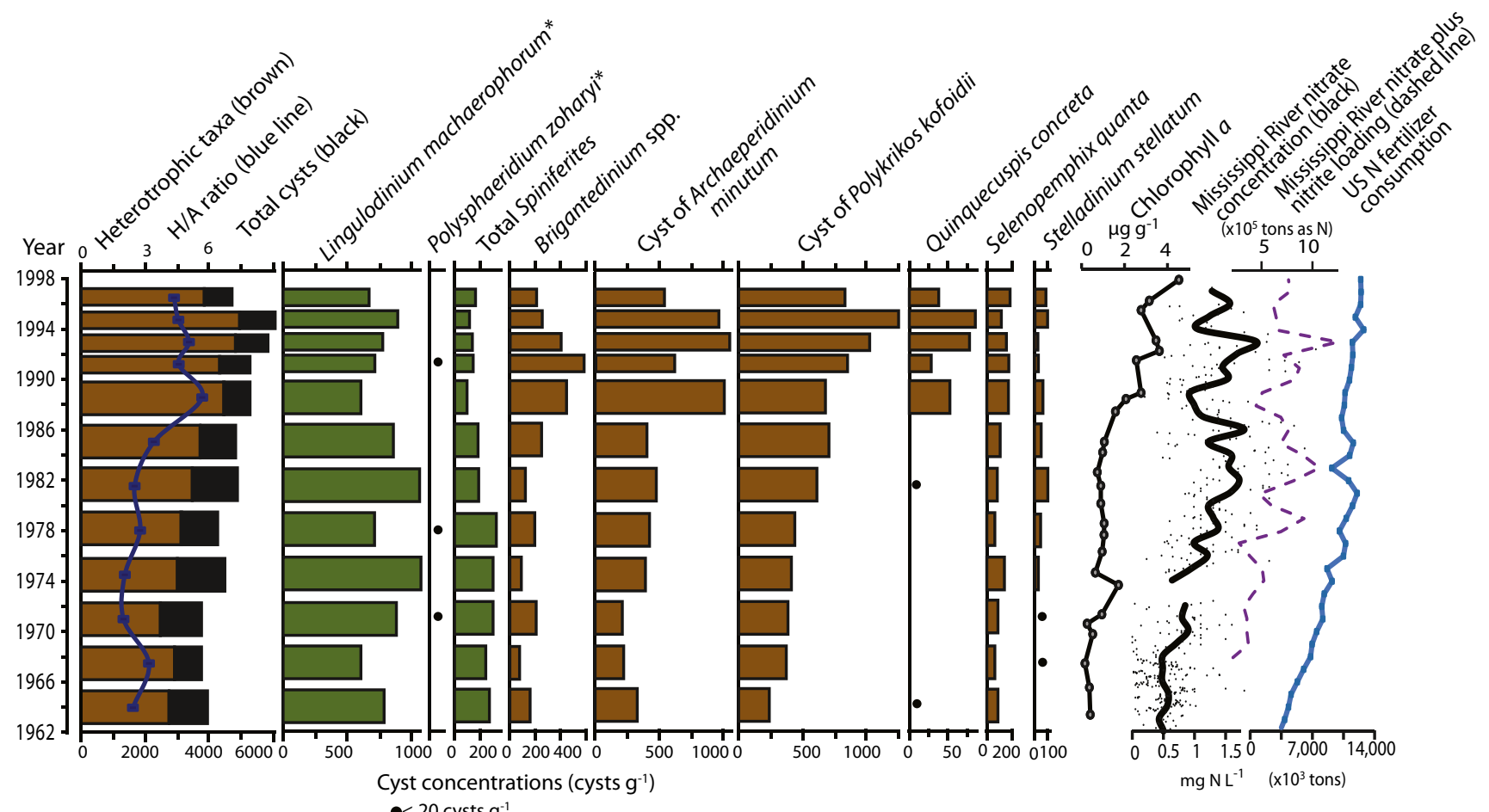

Fig. 5 Core F35. The ratio of heterotrophic to autotrophic taxa (H/A ratio) is shown by a solid line. Concentrations of selected dinoflagellate cyst taxa are shown by bar graphs, where cysts produced by heterotrophic taxa are shown in brown and cysts produced by autotrophic taxa are shown in green. The top four samples are $1 \mathrm{~cm}$ intervals, while the remaining eight samples are $2 \mathrm{~cm}$ intervals. Potentially, toxic taxa are identified with an asterisk (*). Chlorophyll $a$ pigment concentrations from a replicate F35 core (Rabalais et al. 2004 their Figure 2), Mississippi River water nitrate concentrations at St. Francisville where the thick solid black line represents yearly averages, Mississippi River nitrate plus nitrite loading values (USGS, 2016), and the US yearly consumption of nitrogen fertilizer in blue (USDA 2016) 


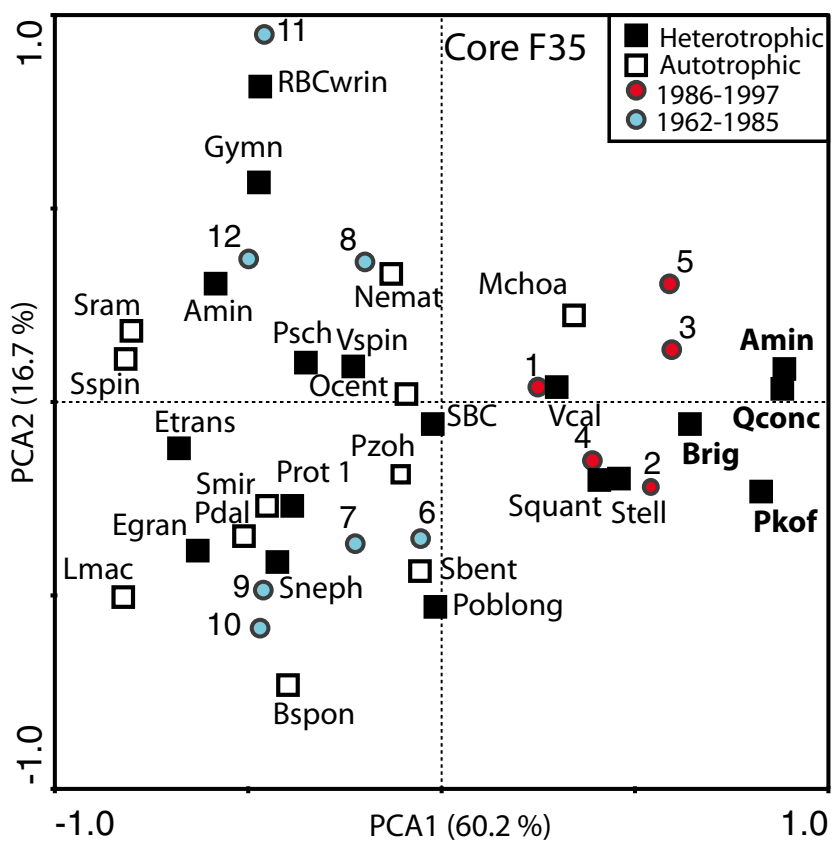

Fig. 6 Principal component analysis (PCA) of dinoflagellate cyst relative abundances in core F35. Full cyst names are listed in ESM 2. Cysts produced by autotrophic taxa are shown by white squares, and cysts produced by heterotrophic taxa are shown by black squares. Numbers refer to sediment core samples starting from the core top (no. $1=1997$, ..., no. $12=1962$ ). Core samples are colored coded, where those with a positive PCA1 score are in red and those with a negative PCA1 score are in blue. The top five samples spanning 1986-1997 have positive PCA1 scores, while the lower seven samples (6-12) span from 1962 to 1985

Dortch 2002; Turner et al. 2004) and Pseudo-nitzschia (Parsons and Dortch 2002). Heterotrophic cyst concentrations show a slight decline in the top sample and may be a result of lower nitrogen loading (Fig. 5).

\section{Spatial Changes in Eutrophication and Environmental Parameters Influencing Cyst Assemblages}

The same four heterotrophic taxa (Brigantedinium spp., $P$. kofoidii, A. minutum, and $Q$. concreta) that increased towards the top of the core were also found to have higher concentrations at stations closest to the mouth of the Mississippi River Delta, especially during 2014 when higher nutrient concentrations were recorded. This supports the use of these taxa as indicators of nutrient-rich plume water in the NGOM. Higher $\mathrm{H} / \mathrm{A}$ ratios were recorded in these same samples suggesting that there may have been an increase in prey availability. In addition, the cyst assemblages were also influenced by other environmental parameters.

The most important and statistically significant environmental parameters influencing cyst assemblages in the NGOM were SSS, SST, and surface water nutrient concentrations, all of which are influenced by the Mississippi River plume. The abundances of heterotrophic taxa correlated with surface water nitrate + nitrite and/or phosphate concentrations (Fig. 4a). In 2006 when Mississippi River discharge was low, SSSs were predictably higher across the shelf. This favored cyst production by autotrophic dinoflagellates, particularly by L. machaerophorum which dominated the assemblage. In contrast, when discharge rates were much higher in 2014 (Price et al. 2017a their Table 2), SSSs were lower across the shelf and nutrients were higher. This favored heterotrophic taxa. The differences in environmental conditions between the two sampling periods resulted in different cyst assemblages, explaining their contrasting sample scores in the CCA (Fig. 4b). Spatially, samples were collected near the mouth of the delta (transects A and/or A') in both 2006 and 2014, yet heterotrophic taxa only dominated in 2014 (Figs. $2 \mathrm{~h}$ and $4 \mathrm{~b}$ ). This can partially be explained by the inter-annual differences in nutrient concentrations. Our hypothesis was that the eutrophication signal recorded by dinoflagellate cysts would manifest itself as an increase in cysts produced by heterotrophic taxa and that concentrations of heterotrophic taxa would be greatest near the major distributaries. Our results support this hypothesis.

In a previous study of surface samples from the Gulf of Mexico, Limoges et al. (2013) reported that distance to the coast and/or water depth and annual temperature were the most important factors controlling cyst distributions in the GOM; however, they did not report which variables included in their analysis (SST, SSS, primary productivity, water depth, distance to coast) were statistically significant. Distance to coast is often a proxy for river-derived nutrients. In our study, there were a greater proportion of heterotrophic taxa on average, compared to the rest of the GOM, reflecting the influence of the nutrient-rich Mississippi River plume.

\section{Description of Eutrophication Indicator Species in the NGOM}

The cyst assemblages from both the core and surface samples suggest that four heterotrophic taxa-Brigantedinium spp., $P$. kofoidii, A. minutum, and Q. concreta - can be considered as indicators of nutrient-rich plume waters in the NGOM. Brigantedinium spp., Polykrikos kofoidii, and Quinquecuspis concreta (Fig. 3a, c, d) are known to reflect nutrient availability in other regions (e.g., Tokyo Bay, Japan, Matsuoka et al. 2003; British Columbia, Canada, Radi et al. 2007; Krepakevich and Pospelova 2010; Northeast Pacific margin, Radi and de Vernal 2004; Sishili Bay, Yellow Sea, China, Liu et al. 2012). These taxa were most abundant at stations located closest to the mouth of the Mississippi River Delta in 2014 (Fig. 3a, c, d), yet they also show slight increases at stations J4 and K4 in the western part of the study area. Some autotrophic species (i.e., Spiniferites ramosus, $P$. zoharyi) are also higher than average at these same western stations (Fig. 3), suggesting a factor that affects both trophic levels. 
Many of these heterotrophic taxa are also found in other deltaic systems. In sediments influenced by plume waters of the Po, Nile, and Rhône rivers, the most common species associated with the plume waters and/or eutrophication are Brigantedinium spp., Polykrikos spp., S. quanta, L. machaerophorum, and Echinidinium spp. (Sangiorgi and Donders 2004; Zonneveld et al. 2009, 2012; Elshanawany et al. 2010). Cyst assemblages in surface sediments near the Fraser River delta (BC, Canada) were dominated by $P$. schwartzii, Brigantedinium spp., Q. concreta, Echinidinium spp., Spiniferites spp., O. centrocarpum, cysts of Pentapharsodinium dalei, cysts of Alexandrium spp., and S. quanta (Radi et al. 2007; Czarnecki et al. 2014).

This is the first study that we know of where A. minutum is an indicator of plume waters. However, this species was only described recently by Yamaguchi et al. (2011), and as it is a small spiny brown cyst, it may have been included in counts of Echinidinium spp. in older studies, given that there are some morphological similarities. It appears to reflect nutrient loading in the NGOM because it had high abundances in the top section of core F35 when Mississippi River nutrient concentrations were greatest, it correlated with higher nutrient concentrations in the surface samples (Fig. 4a) and had the greatest abundances near the mouth of the Mississippi River Delta in 2014 (Fig. 3b). Its association with higher nutrients is supported by Price and Pospelova (2011) who found that this species (reported as Protoperidinium minutum) correlated with biogenic silica flux and therefore nutrient availability, in Saanich Inlet, BC, Canada.

\section{The Current State of NGOM Eutrophication}

The expansion of the seasonal hypoxic zone in the NGOM is a concern and an Action Plan for Reducing, Mitigating, and Controlling Hypoxia in the Northern Gulf of Mexico (Mississippi River/Gulf of Mexico Watershed Nutrient Task Force 2001) promotes actions to address the issue. The goal was to reduce nutrient loading so that the average size of the summer hypoxic zone was less than $5000 \mathrm{~km}^{2}$ by 2015 ; however, this goal was not reached. The extent of the hypoxic zone is just one means of monitoring the effects of excess nutrients. Based on the dinoflagellate cyst eutrophication signal from core F35, eutrophication has been increasing slowly from 1960 to 1985 and worsened over 1986 to 1997 . Eutrophic conditions may have improved in 2006 and 2007, because of the reduced abundances of heterotrophic taxa. However, 2008 and 2014 saw a return of the heterotrophic taxa, implying eutrophication conditions may again have worsened.

\section{Occurrence of Cysts of Potentially Toxic Dinoflagellates}

Toxic dinoflagellates such as Karenia brevis, which forms temporary cysts, are known to bloom in the Gulf of Mexico (e.g., Walsh et al. 2006); however, only a few harmful dinoflagellate species form resistant resting cysts. A recent study of phytoplankton in nearshore coastal waters of Louisiana revealed the presence of the potentially harmful Gymnodinium sp. in 2008 (Schaeffer et al. 2012). The only species of Gymnodinium cysts identified in our study were that of Gymnodinium microreticulatum, which are nontoxic (e.g., Bolch et al. 1999). Polysphaeridium zoharyi, which are cysts of the potentially toxic dinoflagellate Pyrodinium bahamense, were found in both the surface and core sediments. This species occurred in only three samples in the core and in low $\left(<20\right.$ cysts $\left.\mathrm{g}^{-1}\right)$ concentrations (Fig. 5), but were found in almost all surface sediment samples where they comprised up to 72 cysts g $^{-1}$ (Fig. 3g). Some of the highest concentrations of this species were present at stations near the mouths of the Atchafalaya and Mississippi river deltas. Lingulodinium polyedrum, the dinoflagellate producing $L$. machaerophorum cysts, can produce yessotoxins (e.g., Paz et al. 2004) and was the most abundant autotrophic taxon in our study where it comprised up to $74 \%$ of the total assemblage. Lingulodinium polyedrum is often found in high abundances in areas with high nutrients (e.g., Blasco 1975; Thorsen and Dale 1997; Zonneveld et al. 2009; Bringué et al. 2013), yet its relative and absolute abundances were greatest in 2006 when the Mississippi River discharge was lowest and were generally in highest abundances furthest from the river mouths (Fig. 3e).

\section{Conclusions}

Our results showed that four heterotrophic taxaBrigantedinium spp., P. kofoidii, A. minutum, and Q. concreta are indicators of nutrient-rich plume waters in the NGOM and that they track changes in eutrophication. These four heterotrophic taxa increased after 1985 in core F35 and track trends in Mississippi River nitrate concentrations. Furthermore, these taxa were most abundant in surface sediments collected closest to the mouth of the Mississippi River Delta, especially in years with higher Mississippi River discharge, further validating their use as eutrophication indicators in the NGOM. The abundance of these taxa in surface sediments correlated well with higher sea-surface nutrient concentrations and lower summer SSSs, both of which are strongly influenced by river discharge. The average summer sea-surface temperature was also a statistically significant influencing variable; however, its inter-annual and spatial variation was less than $2{ }^{\circ} \mathrm{C}$, and not likely to have been the main driver in the cyst assemblages. This suggests that cyst assemblages can be used as a means to monitor eutrophication in the NGOM and to help document the progress of initiatives such as nitrogenmanagement practices (e.g., Dinnes et al. 2002) that are occurring in the Mississippi River watershed. Dinoflagellate cyst 
assemblages record changes in their environment at various time scales and can be, therefore, used to monitor changes in nutrient loading occurring on a seasonal (sediment traps) to inter-annual (surface sediments) basis. Future work in the study region would benefit from a greater number of surface samples distributed across the shelf and from sediment cores collected more recently to determine trends or changes in the eutrophication status over the last two decades.

Acknowledgements The Natural Science and Engineering Research Council of Canada (NSERC) is acknowledged for providing partial funding via a graduate scholarship (CGS-D3) to AMP and a Discovery Grant to GLC. This work was supported by a Geological Society of America research grant awarded to AMP. We thank Zingyi Zhang and Wonjun Cho for their lab assistance and McGill's work study program that funded them, Wendy Morrison (LUMCON) for her assistance at LUMCON, Charles Milan (Louisiana State University) for his role in dating the sediment core, and Vera Pospelova (University of Victoria), Raja Sengupta (McGill University), and Suzanne Leroy (Brunel University) for their comments on an earlier draft of this manuscript. Support for ship time was provided by the National Oceanic and Atmospheric Administration, Center for Sponsored Coastal Ocean Research, under awards NA06OP0528 and NA09NOS4780204 to Louisiana Universities Marine Consortium, awards NA06OP0529 and NA09NOS4780230 to Louisiana State University, and NGOMEX06 funding to NNR and RET. The crew of the R/V Pelican is thanked for assistance with sample collection. We thank two anonymous reviewers and the editor for their constructive comments which helped improve this manuscript.

\section{References}

Baustian, M.M., N.N. Rabalais, W.L. Morrison, and R.E. Turner. 2011. Seasonal microphytobenthos on the hypoxic northern Gulf of Mexico continental shelf. Marine Ecology Progress Series 436: 51-66. https://doi.org/10.3354/meps09262.

Baustian, M.M., N.N. Rabalais, W.L. Morrison, and R.E. Turner. 2013. Microphytobenthos along the Louisiana continental shelf during mid-summer hypoxia. Continental Shelf Research 52: 108-118. https://doi.org/10.1016/j.csr.2012.10.014.

Benninghoff, W.S. 1962. Calculation of pollen and spore density in sediments by addition of exotic pollen in known quantities. Pollen et Spores 6: 332-333.

Blasco, D. 1975. Red tides in the upwelling regions. In Toxic dinoflagellate blooms, ed. V.R. LoCicero, 113-119. Wakefield: Massachusetts Science and Technology Foundation.

Bolch, C.J.S., A.P. Negri, and G.M. Hallegraeff. 1999. Gymnodinium microreticulatum sp. nov. (Dinophyceae): A naked, microreticulate cyst-producing dinoflagellate, distinct from Gymnodinium catenatum and Gymnodinium nolleri. Phycologia 38 (4): 301-313. https://doi.org/10.2216/i0031-8884-38-4-301.1.

Bringué, M., V. Pospelova, and D. Pak. 2013. Seasonal production of organic-walled dinoflagellate cysts in an upwelling system: A sediment trap study from the Santa Barbara Basin, California. Marine Micropaleontology 100: 34-51. https://doi.org/10.1016/j.marmicro. 2013.03.007.

Bringué, M., V. Pospelova, and D.B. Field. 2014. High resolution sedimentary record of dinoflagellate cysts reflects decadal variability and 20th century warming in the Santa Barbara Basin. Quaternary Science Reviews 105: 86-101. https://doi.org/10.1016/j.quascirev. 2014.09.022.
Czarnecki, J.M., S.E. Dashtgard, V. Pospelova, R.W. Mathewes, and J.A. MacEachern. 2014. Palynology and geochemistry of channelmargin sediments across the tidal-fluvial transition, lower Fraser River, Canada: Implications for the rock record. Marine and Petroleum Geology 51: 152-166. https://doi.org/10.1016/j. marpetgeo.2013.12.008.

Dale, B. 1983. Dinoflagellate resting cysts: 'benthic plankton'. In Survival strategy of the algae, ed. G.A. Fryxell, 69-136. Cambridge: Cambridge University Press.

Dale, B. 1996. Dinoflagellate cyst ecology: Modeling and geological applications. In Palynology: Principles and Applications, ed. J. Jansonius and D.C. McGregor, 1249-1275. Salt Lake city: AASP Foundation.

Dale, B. 2009. Eutrophication signals in the sedimentary record of dinoflagellate cysts in coastal waters. Journal of Sea Research 61 (1-2): 103-113. https://doi.org/10.1016/j.seares.2008.06.007.

Dale, B., and A. Fjellså. 1994. Dinoflagellate cysts as productivity indicators: State of the art, potential and limits. In Carbon cycling in the glacial ocean: Constraints in the ocean's role in global change, ed. R. Zahn, 521-537. Berlin: Springer. https://doi.org/10.1007/978-3642-78737-9 22.

Dale, B., A. Thorsen, and A. Fjellså. 1999. Dinoflagellate cysts as indicators of cultural eutrophication in the Oslofjord, Norway. Estuarine, Coastal and Shelf Science 48 (3): 371-382. https://doi. org/10.1006/ecss.1999.0427.

de Vernal, A., M. Henry, J. Matthiessen, P. Mudie, A. Rochon, K.P. Boessenkool, F. Eynaud, K. Grøsfield, J. Guior, D. Hamel, R. Harland, M.J. Head, M. Kunz-Pirrung, E. Levac, V. Loucheur, O. Peyron, V. Pospelova, T. Radi, J.-L. Turon, and E. Voronina. 2001. Dinoflagellate cyst assemblages as tracers of sea-surface conditions in the northern North Atlantic, Arctic and sub-Arctic seas: The new ' $n=677$ ' data base and its application for quantitative palaeoceanographic reconstruction. Journal of Quaternary Science 16 (7): 681-698. https://doi.org/10.1002/jqs.659.

Dinnes, D.L., D.L. Karlen, D.B. Jaynes, T.C. Kaspar, J.L. Hatfield, T.S. Colvin, and C.A. Cambardella. 2002. Nitrogen management strategies to reduce nitrate leaching in tile-drained Midwestern soils. Agronomy Journal 94 (1): 153-171. https://doi.org/10.2134/ agronj2002.1530.

Edwards, L.E. and D.A. Willard. 2001. Dinoflagellate cysts and pollen from sediment samples, Mississippi Sound and Gulf of Mexico. In Paleontology and Geology of Mississippi Sound sediments, ed. G.S. Gohn, 01-415. Jackson County: U.S. Geological Survey Open-File Report.

Elshanawany, R., K. Zonneveld, M.I. Ibrahim, and S.E.A. Kholeif. 2010. Distribution patterns of recent organic-walled dinoflagellate cysts in relation to environmental parameters in the Mediterranean Sea. Palynology 34 (2): 233-260. https://doi.org/10.1080/ 01916121003711665 .

Goolsby, D.A., W.A. Battaglin, G.B. Lawrence, R.S. Artz, B.T. Aulenbach, R.P. Hooper, D.R. Keeney and G.J. Stensland. 1999. Flux and sources of nutrients in the Mississippi-Atchafalaya River basin: topic 3 report for the integrated assessment of hypoxia in the Gulf of Mexico. NOAA/National Centers for Coastal Ocean Science, 1-130. Silver Springs: NOAA Coastal Ocean Program Decision Analysis Series No. 17.

Hansen, P.J. 1991. Quantitative importance and trophic role of heterotrophic dinoflagellates in a coastal pelagial food web. Marine Ecology Progress Series 73: 253-261. https://doi.org/10.3354/meps073253.

Hansen, P.J., and A.J. Calado. 1999. Phagotrophic mechanisms and prey selection in free living dinoflagellates. Journal of Eukaryotic Microbiology 46 (4): 382-389. https://doi.org/10.1111/j.15507408.1999.tb04617.x.

Jacobson, D.M., and D.M. Anderson. 1986. Thecate heterotrophic dinoflagellates: Feeding behaviour and mechanisms. Journal of 
Phycology 22 (3): 249-258. https://doi.org/10.1111/j.1529-8817. 1986.tb00021.x.

Jeong, H.J. 1999. The ecological roles of heterotrophic dinoflagellates in marine planktonic community. Journal of Eukaryotic Microbiology 46 (4): 390-396. https://doi.org/10.1111/j.1550-7408.1999. tb04618.x.

Jeong, H.J., Y.D. Yoo, J.S. Kim, K.A. Seong, N.S. Kang, and T.H. Kim. 2010. Growth, feeding and ecological roles of the mixotrophic and heterotrophic dinoflagellates in marine planktonic food webs. Ocean Science Journal 45 (2): 65-91. https://doi.org/10.1007/ s12601-010-0007-2.

Kamiyama, T., H. Yamauchi, S. Nagai, and M. Yamaguchi. 2014. Differences in abundance and distribution of Alexandrium cysts in Sendai Bay, northern Japan, before and after the tsunami caused by the Great East Japan Earthquake. Journal of Oceanography 70 (2): 185-195. https://doi.org/10.1007/s10872-014-0221-0.

Kim, S.-Y., C.-H. Moon, H.-J. Cho, and D.-I. Lim. 2009. Dinoflagellate cysts in coastal sediments as indicators of eutrophication: A case of Gwangyang Bay, South Sea of Korea. Estuaries and Coasts 32: $1125-1233$

Krepakevich, A., and V. Pospelova. 2010. Tracing the influence of sewage discharge on coastal bays of Southern Vancouver Island (BC, Canada) using sedimentary records of phytoplankton. Continental Shelf Research 30 (18): 1924-1940. https://doi.org/10.1016/j.csr. 2010.09.002.

Limoges, A., L. Londeix, and A. de Vernal. 2013. Organic-walled dinoflagellate cyst distribution in the Gulf of Mexico. Marine Micropaleontology 102: 51-68. https://doi.org/10.1016/j. marmicro.2013.06.002.

Limoges, A., A. de Vernal, and N. Van Nieuwenhove. 2014. Long-term hydrological changes in the northeastern Gulf of Mexico (ODP625B) during the Holocene and late Pleistocene inferred from organic-walled dinoflagellate cysts. Palaeogeography, Palaeoclimatology, Palaeoecology 414: 178-191. https://doi.org/ 10.1016/j.palaeo.2014.08.019.

Limoges, A., A. de Vernal, and A.-C. Ruiz-Fernández. 2015. Investigating the impact of land use and the potential for harmful algal blooms in a tropical lagoon of the Gulf of Mexico. Estuarine, Coastal and Shelf Science 167B: 549-559.

Liu, D., Y. Shi, B. Di, Q. Sun, Y. Wang, Z. Dong, and H. Shao. 2012. The impact of different pollution sources on modern dinoflagellate cysts in Sishili Bay, Yellow Sea, China. Marine Micropaleontology 8485: 1-13. https://doi.org/10.1016/j.marmicro.2011.11.001.

Lohrenz, S.E., G.L. Fachnenstiel, D.G. Redalje, G.A. Lang, M.J. Dagg, T.E. Whitledge, and Q. Dortch. 1999. Nutrients, irradiance, and mixing as factors regulating primary production in coastal waters impacted by the Mississippi River plume. Continental Shelf Research 19 (9): 1113-1141. https://doi.org/10.1016/S02784343(99)00012-6.

Lundholm, N., S. Ribeiro, T.J. Andersen, T. Koch, A. Godhe, F. Ekelund, and M. Ellegaard. 2011. Buried alive - Germination of up to a century-old marine protist resting stages. Phycologia 50 (6): 629 640. https://doi.org/10.2216/11-16.1.

Marret, F., S.-Y. Kim, and J. Scourse. 2013. A 30,000 record of landocean interaction in the eastern Gulf of Guinea. Quaternary Research 80 (1): 1-8. https://doi.org/10.1016/j.yqres.2013.04.003.

Matsuoka, K. 1999. Eutrophication process recorded in dinoflagellate cyst assemblages - A case of Yokohama Port, Tokyo Bay, Japan. The Science of the Total Environment 231 (1): 17-35. https://doi. org/10.1016/S0048-9697(99)00087-X.

Matsuoka, K., L.B. Joyce, Y. Kotani, and Y. Matsuyama. 2003. Modern dinoflagellate cysts in hypertrophic coastal waters of Tokyo, Japan. Journal of Plankton Research 25 (12): 1461-1470. https://doi.org/ 10.1093/plankt/fbg111.

Mertens, K.N., H. Gu, Y. Takano, A.M. Price, V. Pospelova, K. Bogus, G.J.M. Versteegh, F. Marret, R.E. Turner, N.N. Rabalais, and K.
Matsuoka. 2017. The cyst-theca relationship of the dinoflagellate cyst Trinovantedinium pallidifulvum, with erection of Protoperidinium lousianensis sp. nov. and their phylogenetic position within the Conica group. Palynology 41 (2): 183-202. https:// doi.org/10.1080/01916122.2016.1147219.

Mississippi River/Gulf of Mexico Watershed Nutrient Task Force. 2001. Action plan for reducing, mitigating, and controlling hypoxia in the northern Gulf of Mexico. Washington, D.C.: Office of Wetlands, Oceans, and Watersheds, U.S. Environmental Protection Agency.

Naustvoll, L.-J. 2000. Prey size spectra and food preference in thecate heterotrophic dinoflagellates. Phycologia 39 (3): 187-198. https:// doi.org/10.2216/i0031-8884-39-3-187.1.

Nittrouer, C.A., R.W. Sternberg, R. Carpenter, and T. Bennett. 1979. The use of Pb-210 geochronology as a sedimentological tool: Application to the Washington continental shelf. Marine Geology 31 (3-4): 297-316. https://doi.org/10.1016/0025-3227(79)90039-2.

Nowlin, W.D., A.E. Jochens, S.F. DiMarco, R.O. Reid, and M.K. Howard. 2005. Low-frequency circulation over the TexasLouisiana continental shelf. Circulation in the Gulf of Mexico: Observations and Models 161: 219-240.

Osterman, L.E. 2003. Benthic foraminifers from the continental shelf and slope of the Gulf of Mexico: An indicator of shelf hypoxia. Estuarine, Coastal and Shelf Science 58 (1): 17-35. https://doi. org/10.1016/S0272-7714(02)00352-9.

Osterman, L.E., R.Z. Poore, P.W. Swarzenski, and R.E. Turner. 2005 Reconstructing a $180 \mathrm{yr}$ record of natural and anthropogenic induced low-oxygen conditions from Louisiana continental shelf sediments. Geology 33 (4): 329-332. https://doi.org/10.1130/G21341. 1.

Osterman, L.E., R.Z. Poore, and P.W. Swarzenski. 2008. The last 1000 years of natural and anthropogenic low-oxygen bottom-water on the Louisiana shelf, Gulf of Mexico. Marine Micropaleontology 66 (34): 291-303. https://doi.org/10.1016/j.marmicro.2007.10.005.

Osterman, L.E., P.Z. Poore, P.W. Swarzenski, D.B. Senn, and S.F. DiMarco. 2009. The $20^{\text {th }}$-century development and expansion of Louisiana shelf hypoxia, Gulf of Mexico. Geo-Marine Letters 29 (6): 405-414. https://doi.org/10.1007/s00367-009-0158-2.

Parsons, M.L., and Q. Dortch. 2002. Sedimentological evidence of an increase in Pseudo-nitzschia (Bacillariophyceae) abundance in response to coastal eutrophication. Limnology and Oceanography 47 (2): 551-558. https://doi.org/10.4319/1o.2002.47.2.0551.

Paz, B., P. Riobo, M. Luisa Fernández, S. Fraga, and J.M. Franco. 2004. Production and release of yessotoxins by the dinoflagellates Protoceratium reticulatum and Lingulodinium polyedrum in culture. Toxicon 44 (3): 251-258. https://doi.org/10.1016/j.toxicon.2004.05. 021.

Platon, E., B.K. Sen Gupta, N.N. Rabalais, and R.E. Turner. 2005. Effect of seasonal hypoxia on the benthic foraminiferal community of the Louisiana inner continental shelf: The $20^{\text {th }}$ century record. Marine Micropaleontology 54 (3-4): 263-283. https://doi.org/10.1016/j. marmicro.2004.12.004.

Pospelova, V., and S.-J. Kim. 2010. Dinoflagellate cysts in recent estuarine sediments from aquaculture sites of southern South Korea. Marine Micropaleontology 76 (1-2): 37-51. https://doi.org/10. 1016/j.marmicro.2010.04.003.

Pospelova, V., G.L. Chmura, W.S. Boothman, and J.S. Latimer. 2002. Dinoflagellate cyst records and human disturbance in two neighboring estuaries, New Bedford Harbor and Apponagansett Bay, Massachusetts (USA). The Science of the Total Environment 298 (1-3): 81-102. https://doi.org/10.1016/S0048-9697(02)00195-X.

Pospelova, V., S. Esenkulova, S.C. Johannessen, M.C. O'Brien, and R.W. Macdonald. 2010. Organic-walled dinoflagellate cyst production, composition and flux from 1996 to 1998 in the central Strait of Georgia (BC, Canada): A sediment trap study. Marine Micropaleontology 75 (1-4): 17-37. https://doi.org/10.1016/j. marmicro.2010.02.003. 
Powell, A.J., J. Lewis, and J.D. Dodge. 1992. The palynological expressions of post-Palaeogene upwelling: A review. The Geological Society 64 (1): 215-226. https://doi.org/10.1144/GSL.SP.1992.064. 01.14 .

Price, A.M., and V. Pospelova. 2011. High-resolution sediment trap study of organic-walled dinoflagellate cyst production and biogenic silica flux in Saanich Inlet (BC, Canada). Marine Micropaleontology 80 (1-2): 18-43. https://doi.org/10.1016/j.marmicro.2011.03.003.

Price, A.M., K.N. Mertens, V. Pospelova, T.F. Pedersen, and R.S. Ganeshram. 2013. Late Quaternary climatic and oceanographic changes in the Northeast Pacific as recorded by dinoflagellate cysts from Guaymas Basin, Gulf of California (Mexico). Paleoceanography 28 (1): 200-212. https://doi.org/10.1002/palo. 20019.

Price, A.M., M.M. Baustian, R.E. Turner, N.N. Rabalais, and G.L. Chmura. 2017a. Melitasphaeridium choanophorum-A living fossil dinoflagellate cyst in the Gulf of Mexico. Palynology 41 (3): 351-358. https://doi.org/10.1080/01916122.2016.1205676.

Price, A.M., M.R.S. Coffin, V. Pospelova, J.S. Latimer, and G.L. Chmura. 2017b. Effect of nutrient pollution on dinoflagellate cyst assemblages across estuaries of the NW Atlantic. Marine Pollution Bulletin 121 (1-2): 339-351. https://doi.org/10.1016/j.marpolbul. 2017.06.024.

Rabalais, N.N., R.E. Turner, D. Justic, Q. Dortch, and W.J. Wiseman Jr. 1999. Characterization of hypoxia: Topic 1 report for the integrated assessment of hypoxia in the Gulf of Mexico. NOAA/National Centers for Coastal Ocean Science, 1-167. Silver Spring: NOAA Coastal Ocean Program Decision Analysis Series No. 15.

Rabalais, N.N., and R.E. Turner. 2001. Hypoxia in the Northern Gulf of Mexico: Description, causes and change. In Coastal hypoxia: Consequences for living resources and ecosystems. Coastal and estuarine studies, ed. N.N. Rabalais and R.E. Turner, vol. 58, $1-$ 36. Washington, D.C.: American Geophysical Union. https://doi. org/10.1029/CE058p0001.

Rabalais, N.N., N. Atilla, C. Normandeau, and R.E. Turner. 2004. Ecosystem history of Mississippi River-influence continental shelf revealed through preserved phytoplankton pigments. Marine Pollution Bulletin 49 (7-8): 537-547. https://doi.org/10.1016/j. marpolbul.2004.03.017.

Rabalais, N.N., R.E. Turner, B.K. Sen Gupta, D.F. Boesch, P. Chapman, and M.C. Murrell. 2007a. Hypoxia in the Northern Gulf of Mexico: Does the science support the plan to reduce, mitigate, and control hypoxia? Estuaries and Coasts 30 (5): 753-772. https://doi.org/10. 1007/BF02841332.

Rabalais, N.N., R.E. Turner, B.K. Sen Gupta, E. Platon, and M.L. Parsons. 2007b. Sediments tell the history of eutrophication and hypoxia in the northern Gulf of Mexico. Ecological Applications 17 (5): S129-S143. https://doi.org/10.1890/06-0644.1.

Radi, T., and A. de Vernal. 2004. Dinocyst distribution in surface sediments from the northeastern Pacific margin $\left(40-60^{\circ} \mathrm{N}\right)$ in relation to hydrographic conditions, productivity and upwelling. Review of Palaeobotany and Palynology 128 (1-2): 169-193. https://doi.org/ 10.1016/S0034-6667(03)00118-0.

Radi, T., V. Pospelova, A. de Vernal, and J.V. Barrie. 2007. Dinoflagellate cysts as indicators of water quality and productivity in British Columbia estuarine environments. Marine Micropaleontology 62 (4): 269-297. https://doi.org/10.1016/j.marmicro.2006.09.002.

Sangiorgi, F., and T.H. Donders. 2004. Reconstructing 150 years of eutrophication in the north-western Adriatic Sea (Italy) using dinoflagellate cysts, pollen and spores. Estuarine, Coastal and Shelf Science 60 (1): 69-79. https://doi.org/10.1016/j.ecss.2003.12.001.

Scavia, D., N.N. Rabalais, and R.E. Turner. 2003. Predicting the response of Gulf of Mexico hypoxia to variations in Mississippi River nitrogen load. Limnology and Oceanography 48 (3): 951-956. https:// doi.org/10.4319/1o.2003.48.3.0951.
Schaeffer, B.A., J.C. Kurtz, and M.K. Hein. 2012. Phytoplankton community composition in nearshore coastal waters of Louisiana. Marine Pollution Bulletin 64 (8): 1705-1712. https://doi.org/10. 1016/j.marpolbul.2012.03.017.

Sen Gupta, B.K., R.E. Turner, and N.N. Rabalais. 1996. Seasonal oxygen depletion in continental-shelf waters of Louisiana: Historical record of benthic foraminifers. Geology 24 (3): 227-230. https://doi.org/10. 1130/0091-7613(1996)024<0227:SODICS>2.3.CO;2.

Shin, H.H., K. Mizushima, S.J. Oh, J.S. Park, I.H. Noh, M. Iwataki, K. Matsuoka, and Y.H. Yoon. 2010. Reconstruction of historical nutrient levels in Korean and Japanese coastal areas based on dinoflagellate cyst assemblages. Marine Pollution Bulletin 60 (8): 1243-1258. https://doi.org/10.1016/j.marpolbul.2010.03.019.

ter Braak, C.J.F., and P. Šmilauer. 2002. Canoco reference manual and CanoDraw for Windows user's guide. Software for canonical community ordination (version 4.5). Ithaca: Microcomputer Power.

ter Braak, C.J.F., and P. Šmilauer. 2012. Canoco reference manual and user's guide: software for ordination (version 5.0). Ithaca: Microcomputer Power.

Thorsen, T.A., and B. Dale. 1997. Dinoflagellate cysts as indicators of pollution and past climate in a Norwegian fjord. The Holocene 7 (4): 433-446. https://doi.org/10.1177/095968369700700406.

Turner, R.E., C.S. Milan, and N.N. Rabalais. 2004. A retrospective analysis of trace metals, $\mathrm{C}, \mathrm{N}$, and diatom remnants in sediments from the Mississippi River delta shelf. Marine Pollution Bulletin 49 (7-8): 548-556. https://doi.org/10.1016/j.marpolbul.2004.03.013.

United States Department of Agriculture. 2016. Fertilize use and price. http:/www.ers.usda.gov/data-products/fertilizer-use-and-price. aspx\#.U8VQPFandUM. Accessed 12 July 2013.

USGS. 2016. Streamflow and nutrient delivery to the Gulf of Mexico. United States Geological Survey. http://toxics.usgs.gov/hypoxia/ mississippi/flux ests/delivery/index.html. Accessed 26 July 2016.

Van Soelen, E.E., E.I. Lammertsma, H. Cremer, T.H. Donders, F. Sangiorgi, G.R. Brooks, R.A. Larson, J.S. Sinninghe Damsté, F. Wagner-Cremer, and G.J. Reichart. 2010. Late Holocene sea-level rise in Tampa Bay: Integrated reconstruction using biomarkers, pollen, organic-walled dinoflagellate cysts, and diatoms. Estuarine, Coastal and Shelf Science 86 (2): 216-224. https://doi.org/10. 1016/j.ecss.2009.11.010.

Wall, D., and B. Dale. 1968. Modern dinoflagellate cysts and evolution of the Peridiniales. Micropaleontology 14 (3): 265-304. https://doi.org/ $10.2307 / 1484690$

Wall, D., B. Dale, G.P. Lohmann, and W.K. Smith. 1977. The environmental and climatic distribution of dinoflagellate cysts in modern marine sediments from regions in the North and South Atlantic Oceans and adjacent seas. Marine Micropaleontology 2: 121-200. https://doi.org/10.1016/0377-8398(77)90008-1.

Walsh, J.J., J.K. Jolliff, B.P. Darrow, J.M. Lenes, S.P. Milroy, A. Remsen, D.A. Dieterle, K.L. Carder, F.R. Chen, G.A. Vargo, R.H. Weisberg, K.A. Fanning, F.E. Muller-Karger, E. Shinn, K.A. Steidinger, C.A. Heil, C.R. Tomas, J.S. Prospero, T.N. Lee, G.J. Kirkpatrick, T.E. Whitledge, D.A. Stockwell, T.A. Villareal, A.E. Jochens, and P.S. Bontempi. 2006. Red tides in the Gulf of Mexico: Where, when, and why? Journal of Geophysical Research: Oceans 111 (11): C11003. https://doi.org/10.1029/2004JC002813.

White, M.J., C. Santhi, N. Kannan, J.G. Arnold, D. Harmel, L. Norfleet, P. Allen, M. DiLuzio, X. Wang, J. Atwood, E. Haney, and M. Vaughn Johnson. 2014. Nutrient delivery from the Mississippi River to the Gulf of Mexico and effects on cropland conservation. Journal of Soil and Water Conservation 69 (1): 26-40. https://doi. org/10.2489/jswc.69.1.26.

Wrenn, J.H. 1988. Differentiating species of the dinoflagellate cyst genus Nematosphaeropsis. Deflandre and Cookson, 1955. Palynology 12 (1): 129-150. https://doi.org/10.1080/01916122.1988.9989340.

Yamaguchi, A., M. Hoppenrath, V. Pospelova, T. Horiguchi, and B.S. Leander. 2011. Molecular phylogeny of the marine sand-dwelling 
dinoflagellate Herdmania litoralis and an emended description of the closely related planktonic genus Archaeperidinium Jörgensen. European Journal of Phycology 46 (2): 98-112. https://doi.org/10. 1080/09670262.2011.564517.

Zonneveld, K.F., and V. Pospelova. 2015. A determination key for modern dinoflagellate cysts. Palynology 39 (3): 387-409. https://doi.org/ 10.1080/01916122.2014.990115.

Zonneveld, K.A.F., L. Chen, J. Mobius, and M.S. Mahmoud. 2009. Environmental significance of dinoflagellate cysts from the proximal part of the Po-river discharge plume (off southern Italy, Eastern Mediterranean). Journal of Sea Research 62 (4): 189-213. https:// doi.org/10.1016/j.seares.2009.02.003.

Zonneveld, K.A.F., G.J.M. Versteegh, S. Kasten, T.I. Eglinton, K.-C. Emeis, C. Huguet, B.P. Koch, G.J. De Lange, J.W. De Leeuw, J.J. Middelburg, G. Mollenhauer, F.G. Prahl, J. Rethemeyer, and S.G. Wakeham. 2010. Selective preservation of organic matter in marine environments: Processes and impact on the sedimentary record. Biogeosciences 7 (2): 483-511. https://doi.org/10.5194/bg-7-4832010.
Zonneveld, K.A.F., L. Chen, R. Elshanawany, H.W. Fischer, M. Hoins, M.I. Ibrahim, D. Pittauerova, and G.J.M. Versteegh. 2012. The use of dinoflagellate cysts to separate human-induced from natural variability in the trophic state of the Po River discharge plume over the last two centuries. Marine Pollution Bulletin 64 (1): 114-132. https://doi.org/10.1016/j.marpolbul.2011.10.012.

Zonneveld, K.A.F., F. Marret, G.J.M. Versteegh, K. Bogus, S. Bonnet, I. Bouimetarhan, E. Crouch, A. de Vernal, R. Elshanawany, L. Edwards, O. Esper, S. Forke, K. Grøsfjeld, M. Henry, U. Holzwarth, J.-F. Kielt, S.-Y. Kim, S. Ladouceur, D. Ledu, L. Chen, A. Limoges, L. Londeix, S.-H. Lu, M.S. Mahmoud, G. Marino, K. Matsouka, J. Matthiessen, D.C. Mildenhal, P. Mudie, H.L. Neil, V. Pospelova, Y. Qi, T. Radi, T. Richerol, A. Rochon, F. Sangiorgi, S. Solignac, J.-L. Turon, T. Verleye, Y. Wang, Z. Wang, and M. Young. 2013. Atlas of modern dinoflagellate cyst distribution based on 2405 data points. Review of Palaeobotany and Palynology 191: 1-197. https://doi.org/10.1016/j.revpalbo.2012.08.003. 